Szociológiai Szemle 28(2): 136-138.

\title{
Neves közgazdászok köszöntötték előadá- saikkal Budapesten Kornai Jánost a 90. születésnapján - beszámoló a Kornai90 konferenciáról
}

\author{
Hajdu Miklós \\ https://doi.org/10.51624/SzocSzemle.2018.2.7
}

Kornai János, a Harvard Egyetem és a Budapesti Corvinus Egyetem (BCE) emeritus professzora számos, a tervgazdaságok múködését leíró fogalom és elemzés világszerte elismert megalkotója idén januárban lett 90 éves. Ennek megünneplésére a Corvinuson az év elején előadásokat és mühelybeszélgetéseket szerveztek kiváló közgazdászok, például Olivier Blanchard és Gérard Roland meghívásával. Az eseménysorozat egy nemzetközi konferenciával zárult február 21-22. között, ahol szintén a tudomány jeles képviselői adtak elő.

A konferenciát a Nobel-díjas Erik Maskin, Kornai többszörös szerzőtársa és harvardi kollégája nyitotta, aki a Kornai által a hetvenes és a nyolcvanas évek fordulóján bevezetett puha költségvetési korlát fogalmáról tartott előadást. A fogalom azt a jelenséget írja le, amikor a pénzügyi korlátjaikon túllépő, vagyis veszteségesen müködő vállalatok a csődöt a központi állam rendszeres anyagi támogatásával kerülik el. Maskin kiemelte, hogy a puha költségvetési korlát az egyik kulcstényezője volt a szovjet és a kelet-európai gazdaságok nem hatékony múködésének. Ugyanakkor meglepő módon nem foglalkozott azzal, hogy a fogalom némi kiegészítéssel - a szelektivitással, amikor csak a vállalatok bizonyos köre részesül az állam segítségéből napjainkban is nagyon aktuális, méghozzá Kínában (sőt Magyarországon is), pedig a konferencia jelentős része a kínai gazdasági helyzet értékeléséről szólt.

A Kornai által megalkotott fogalmak és elemzési keretek nagyon fontos perspektívát adnak a kínai helyzet vizsgálatához, és a tudós maga is sokat foglalkozott az országgal pályája során. Kornai és Maskin számos kínai PhD-hallgatót tutorált a Harvardon, akik közül többen meghívottként vettek részt a konferencián. A volt hallgatók ráadásul szinte mind magas tudományos pozíciókat töltenek be kínai egyetemeken és más akadémiai intézményekben, így nem meglepő módon számos előadás és kerekasztal-beszélgetés foglalkozott Kína helyzetével. Ráadásul mindez szokatlanul bensőséges, oldott hangnemben történt, köszönhetően annak, hogy a kínai meghívottakon kívül a többi résztvevő és előadó jelentős része is kapcsolatban állt Kornaival.

Amellett, hogy a konferencia nagyon családias, de legalábbis barátságos hangulatban telt, Hszi Csin-ping legújabb intézkedései és a magyar választások közeledte 
rendkívül izgalmassá is tette a kerekasztal-beszélgetéseket és az előadásokat. A Kínáról szóló szekció előadásai közül kiemelhető Chenggang Xu, a Cheung Kong Graduate School of Business közgazdász professzorának előadása, aki emlékeztette a közönséget arra, hogy a 2000-es években a kínai magánszektor gyors bővülésével visszaesett a Kínai Kommunista Párt taglétszáma, ráadásul a nyugatra vándorolt kínaiak többnyire kritikussá váltak Kína vezetése iránt. Ezekre a kihívásokra a párt kétféleképp reagált: (1) a párthú személyeket anyagi támogatásban részesítette (vagy másképp fogalmazva megvásárolta), (2) elnyomást tanúsított.

A legfontosabb előadást viszont Chong-en Bai, a Tsinghua University's School of Economics and Management dékánhelyettese tartotta Kínáról. Bai már árnyaltabban foglalkozott a puha költségvetési korláttal Maskinhoz képest, és kitért arra, hogy ez a jelenség szelektíven mutatkozik meg Kínában. A helyi kormányzatok ugyanis különböző módokon segítik az általuk preferált cégeket, miközben megnehezítik más vállalkozások múködését. Hszi Csin-ping, aki a lokális hatalmi pólus meggyengítésére törekszik, korrupcióellenes programjával részben éppen ezen gyakorlat ürügyén érte el számos, a helyi igazgatásban dolgozó tisztviselő bebörtönzését.

Kornai kínai tanítványai azonban nem csak előadásaikon, hanem egy kerekasztal-beszélgetésen is megosztották véleményüket országuk helyzetéről Székely-Doby András, a BCE docensének moderálása mellett. Kiemelték a magántulajdon és az irányított gazdaság kettősségéből eredő egymásrautaltságot a kormányzat és a magánvállalatok között - például a kormány érdekeltségét olyan cégekben, mint az Alibaba. Szóba került az is, hogy Kínában a földterületek állami tulajdonban vannak, a helyi kormányzatok kezelik azokat. Tehát amennyiben egy magánvállalkozásnak földre van szüksége, a lokális hatalommal kell egyezkednie - és ezen a ponton tud megnyilvánulni a szelektív puha költségvetési korlát, ugyanis az önkormányzatok befolyásolni tudják, hogy ha például földalapú hitelt venne fel egy cég, mekkora földterületet kell felmutatnia fedezetül.

Philippe Aghion, a Collège de France, a Harvard Egyetem és a London School of Economics professzora a magyarországi történésekre reflektált előadásában. A szimulált demokrácia fogalmával - amikor ugyan léteznek a demokratikus intézmények, de múködésük korlátozott, legalábbis a demokratikus értékek fenntartásának szempontjából - írta le a magyar helyzetet. Felhívta a közönség figyelmét a köz- és a felsőoktatás, illetve az egészségügy centralizálásának negatív következményeire az intézményrendszer müködésében.

Az elmúlt néhány év magyarországi eseményeit dolgozta fel több szekció is. Többek között szó volt a populizmus magyarországi előretöréséről Győrfy Dóra, Ádám Zoltán és Bartha Attila előadásain. A politikai és adminisztratív elit különös euroszkepticizmusáról Lengyel György értekezett, míg Tóth István János és Martin József Péter a kormányközeli vállalkozók kiemelkedését és sikereit értékelték. A magánnyugdíjpénztárak felszámolását Csaba László, az önkormányzatok adósságának állami átvállalását Vasvári Tamás elemezte, Semjén András és Deák Dániel pedig 
az oktatási reformok aggasztó következményeit mutatták be - és a lista még hosszan sorolható lenne, például Bokros Lajos és Mellár Tamás is az előadók között volt. A prezentációk végkövetkeztetései többnyire egységesek voltak abban a tekintetben, hogy a Kornai által U-kanyarnak nevezett politikai irányváltás ${ }^{1}$ bekövetkezését támasztották alá az államigazgatás különböző területein.

Mindemellett voltak elméleti és történeti megközelítésű előadások is, amelyek szintén Kornai munkásságára hivatkoztak, például Szelényi Iván és Geoffrey Hodgson - a University of Hertfordshire kutatóprofesszora - záróelőadásai. Azonban Kornai elméleteinek gyakorlati alkalmazásai, az aktuális történések megmagyarázása sokkal hangsúlyosabb részét adták a konferenciának. Kornai maga is több tanulmányt írt mind a kínai, mind pedig a magyar fejleményekről az utóbbi néhány évben, és záró beszédében elkötelezte magát a konferenciára benyújtott tanulmányok kötetbe rendezése mellett.

12010 előtt Magyarország a demokrácián, a jogállamiságon és a magántulajdon dominanciáján alapuló piacgazdaság felé haladt, azonban a 2010. évi kormányváltással ez az irány az ellenkezőjére változott, Kornai szóhasználatával élve egy éles U-kanyarral. 